\title{
Evaluation of analgesic and anti-inflammatory properties of the Allium cepa extract in rats
}

\author{
Purna Prasad Meegada ${ }^{1}$, Rama Mohan Pathapati ${ }^{2}$, Sriharsha Rayam $^{1 *}$, \\ Raveendra Kumar Nallabothula ${ }^{1}$
}

\author{
${ }^{1}$ Department of Pharmacology, Katuri Medical College, Guntur, Andhra Pradesh, India \\ ${ }^{2}$ Department of Pharmacology, Narayana Medical College, Nellore, Andhra Pradesh, India
}

Received: 23 April 2021

Accepted: 28 May 2021

*Correspondence:

Dr. Sriharsha Rayam,

Email: sriharsharayam@gmail.com

Copyright: (c) the author(s), publisher and licensee Medip Academy. This is an open-access article distributed under the terms of the Creative Commons Attribution Non-Commercial License, which permits unrestricted non-commercial use, distribution, and reproduction in any medium, provided the original work is properly cited.

\begin{abstract}
Background: The onion plant (Allium cepa) is the most widely cultivated species of the genus Allium. It has antibiotic, antidiabetic, antihypercholesterolemic, antioxidant, hemostatic, antimutagenic effects. The current study is aimed to evaluate analgesic and anti-inflammatory properties of Allium cepa extracts in rat models.

Methods: In this study analgesic activity in rats is tested by Eddy's hot plate method, tail flick method. In Eddy's hot plate method rats are individually placed on the heated plate of the analgesic meter maintained at $55^{\circ} \mathrm{C}$ and mean reaction time was calculated at regular time intervals. In tail flick method the tail withdrawal from the heat (flicking response) is taken as the end point. Anti-inflammatory property is studied by carrageenan induced paw edema model, in which the paw volume is measured with a plethysmograph.

Results: In Eddy's hot plate method the mean reaction time increased significantly $(\mathrm{p}<0.05)$ with high dose of Allium cepa at 1 hour and 2 hours when compared to control. In tail flick method the mean reaction time is increased significantly $(\mathrm{p}<0.05)$ with high dose of Allium cepa at 1 hour and 1.5 hour when compared to control. In carrageenan induced paw edema method Allium cepa exhibited anti-inflammatory activity by significant $(\mathrm{p}<0.05)$ suppression of paw edema when compare to control at 1 hour after carrageenan injection to rat paw.

Conclusions: Allium cepa has significant analgesic and anti-inflammatory activity in hot plate, tail flick and carrageenan induced paw edema model.
\end{abstract}

Keywords: Allium Cepa, Analgesic and anti-inflammatory activity, Rats

\section{INTRODUCTION}

Medicinal plants are the major components of all indigenous or alternative systems of medicine. Medicinal plants are sources and can be a good start for the discovery of new chemical compound which leads to new drug. ${ }^{1}$

The international association for the study of pain (IASP) defines pain as an unpleasant sensory and emotional experience associated with actual or potential tissue damage or described in terms of such damage. Pain is a worldwide burden; across the globe, one in five adults suffers from pain. ${ }^{2}$ The inflammatory response, or inflammation, is a physiologic response to tissue injury and infection, although it should be clear that inflammation is not a synonym for infection. The Romans described the characteristics of this response almost 2000 years ago: pain (dolor), heat (calor), redness (rubor), and swelling (tumor). Within minutes of tissue injury and infection, plasma proteins mediate an increase in vascular diameter (vasodilation) and vascular permeability. $^{3}$ 
The onion plant (Allium cepa), also known as the bulb onion or common onion is the most widely cultivated species of the genus Allium. Modern varieties typically grow to a height of 15 to $45 \mathrm{~cm}$ (6 to 18 inches). The leaves are yellowish-green and grow alternately in a flattened, fan-shaped swathe. They are fleshy, hollow and cylindrical, with one flattened side. Most onion cultivars are about $89 \%$ water, $4 \%$ sugar, $1 \%$ protein, $2 \%$ fiber and $0.1 \%$ fat. Onions are low in fats, and have an energy value of $40 \mathrm{kcal}$ per $100 \mathrm{~g}$ serving. ${ }^{4}$ Allium cepa is known to contain many vitamins and minerals and is rich in Sulphur amino acids. Moreover, a variety of secondary metabolites has been identified in this species, such as flavonoids (particularly flavanols andanthocyanin), phytosterols and saponins. ${ }^{5}$ Allium cepa exhibit antibiotic activity against both Gram-positive and Gram-negative bacteria. ${ }^{6}$ Sulfur compounds including S-methyl cysteine and flavonoids such as quercetin are mainly responsible for the hypoglycemic activity of Allium cepa. S-methyl cysteine and flavonoids help to decrease the levels of blood glucose, serum lipids, oxidative stress, and lipid peroxidation, as well as increasing antioxidant enzyme activity and insulin secretion. Extracts of onion also have been shown to have hypoglycemic and hypolipidemic effects by normalizing the activities of liver hexokinase, glucose 6-phosphatase and HMG coenzyme-A reductase. ${ }^{7}$ The antihyper-lipidemic activity of Allium cepa was studied in vivo on mice. A. cepa skin extract effectively decreased plasma triacylglycerol level elevation after administration of a lipid emulsion in rats and it was also able to prevent the body weight gain induced by a high-fat $\operatorname{diet}^{8}$.Antimutagenic effects was demonstrated in a study of six healthy non-obese normocholesterolemic females (age 20-44 years), a meal of fried onions or a meal of fried onions and fresh cherry tomatoes increased resistance of lymphocyte DNA to DNA strand breakage. ${ }^{9}$ In a clinical study of subjects with arterial hypertension (WHO class I), an onion-olive oil maceration product significantly decreased systolic blood pressure; there was also a trend towards a decrease in diastolic blood pressure. In a clinical study in healthy subjects, an onion-olive oil maceration product nonsignificantly decreased arterial blood pressure. ${ }^{10}$ Taking this into consideration the reported various pharmacological effects of Allium cepa in various animal models, ignited aspire to evaluate analgesic and antiinflammatory properties of the Allium cepa extract in rat models.

\section{METHODS}

\section{Animals}

This study was executed in the department of pharmacology, Narayana Medical College. The animals (Wister strain albino rats) weighing 150-250 gms were obtained from central animal house of Narayana Medical College, Nellore for all the animal experiments. They were housed in standard polypropylene cages. Colony breeds Albino rats of either sex weighing between150-
250 gms were included in this study. The animals were excluded if the weight of rats was below 150 gms and if they had any visible diseases. The animals were maintained under standard laboratory conditions (light period of $12 \mathrm{hrs}$ /day and temperature $25^{\circ} \mathrm{C} \pm 1^{\circ} \mathrm{C}$ ) with free access to food and water adlibitum. None of the animal were sacrificed.

\section{Plant material}

Preparation of extract: fresh onions were obtained locally. Aqueous extract was prepared as on the day of experiments the onions were pealed, weighed and crushed well in an electrical mixer grinder. Then the crushed product was filtered using sterile filter papers with 40 micrometers mesh size. The transparent liquid obtained was used freshly within six hours after preparation to investigate the possible analgesic and antiinflammatory effects Albino rats of male sex weighing from 150-250 gms were used in this study. ${ }^{11}$ These were acclimatized to their environment for one week prior to experimentation. The animals were randomly distributed into four different groups. Each experimental group consisted of 6 animals. Each group was caged separately after recording its body weight and the animals were marked with marker for identification. In current study analgesic activity in rats was tested by Eddy's hot plate method and tail flick method.

\section{Eddy's hot plate method ${ }^{12}$}

Principle: In this method heat is used as a source of pain. Animals are individually placed on a hot plate maintained at constant temperature $\left(55^{\circ} \mathrm{C}\right)$ and the reaction of animals such as paw liking or jump response is taken as the end point. Analgesic drugs increase the reaction time. The method was first described by Eddys and Leimbach (1953).

Procedure: All the preparations are administered orally. Albino rats are screened by placing them on a hot plate maintained at $55 \pm 2^{\circ} \mathrm{C}$ with the help of thermostat and the time until either licking or jumping occurs, was recorded by a stop watch. A cut-off period of 25 seconds was maintained to avoid damage to the paw. The pain reaction time was placed on the hot plate and the time the animal lifted up or licked its hind legs or jumped out of the chamber. After $1 \mathrm{hr}$ of administration of normal saline, ibuprofen and Allium cepa, rats are individually placed on the heated plate of the analgesiometer maintained at $55^{\circ} \mathrm{C}$. Reaction time was observed again at $0,30,60$, 90,120,180 and 240 minutes after drug administration and mean response time was calculated.

\section{Tail flick method ${ }^{12}$}

Principle: Analgesic is defined as a state of reduced awareness to pain and analgesic is substance ail which decrease pain sensation by increasing threshold to painful stimuli. Painful reaction in experimental animals can be 
produced by applying noxious stimuli such as thermal (radiant heat). In laboratory commonly used procedures are tail flick (tail withdraw from the radiant heat).

Procedure: Take basal reaction time to radiant heat placing the tip (last $1-2 \mathrm{~cm}$ ) of the tail on the radiant heat source. The tail withdrawal from the heat (flicking response) is taken as the end point. Normally a rat withdraws its tail within 3-5 seconds. A cut of period of 10-12 seconds was observed to prevent damage to the tail. Any animal failing to withdraw its tail in 3-5 seconds was rejected from the study. Take at least 3-5 basal reaction times for each rat at a gap of 5 min to confirm normal behavior of the animal. Oral ibuprofen and note the reaction time $0,30,60,90,120,180$ and 240 minutes after the drug. As the reaction time reaches $10 \mathrm{sec}$ it is considered maximum analgesia and the tail is removed from the source of heat to avoid tissue damage. Antiinflammatory property is studied by carrageenan induced paw edema method.

\section{Plethysmograph ${ }^{12}$}

Principle: Inflammation is a tissue reaction to injury irritation of foreign substance. It is a part of the host defence mechanism but then it becomes uncontrolled it is a hope less condition. There are several tissue factors or mechanism that is known to be involved in the inflammatory reaction such as release of histamine bradykinin and prostaglandins. substance such as carrageenan, formalin, bradykinin, hisamine, 5hydroxytrytamine, mustard or egg white when injected in the dorsum of the foot of the rats they produce acute paw edema within a few minutes of the injection.

Procedure: All the preparations are administered orally. After $1 \mathrm{hr}$ of administration of normal saline, Ibuprofen and Allium cepa, $0.1 \mathrm{ml}$ of $1 \%$ carrageenan solution was injected into the sub plantar region of the right hind paw of the rats. The paw volume was measured with a plethysmograph at $0,0.5,1.0,1.5,2.0,3.0$ and $4.0 \mathrm{hr}$ after administration of the drug and the extract. The average paw swelling in the group of the drug treated rats was compared with untreated control rats.

\section{Statistical analysis}

The data was collected in case record forms. Then they were entered into excel spreadsheet 2007. Statistical analysis was performed using Microsoft Excel-2007 and Sigma graph pad prism version-5 USA. Data was described as mean \pm standard deviation. One way ANOVA followed by post hoc Bonferroni multiple comparison tests was used for analysis of data among all groups. All the results of test drug (Allium cepa) were compared with control. For all inferential statistical tests, a two tailed $\mathrm{p}$ value of less than 0.05 was considered significant.

\section{RESULTS}

\section{Hot plate method}

The mean reaction time in control group at $0 \mathrm{hr}$ was $18 \pm 1.5 \mathrm{sec}$, at $0.5 \mathrm{hr} 13 \pm 1.3 \mathrm{sec}$, at $1 \mathrm{hr} 13 \pm 2.6 \mathrm{sec}$, at 1.5 hr $14 \pm 1.6 \mathrm{sec}$, at $2 \mathrm{hr} 15 \pm 2.9 \mathrm{sec}$, at $3 \mathrm{hr} 13 \pm 1.3 \mathrm{sec}$ and at $4 \mathrm{hr} 15 \pm 1.3 \mathrm{sec}$. For Allium cepa low dose group the mean reaction time at $0 \mathrm{hr} 16 \pm 1.9 \mathrm{sec}$, at $0.5 \mathrm{hr} 19 \pm 2.1 \mathrm{sec}$, at 1 hr $18 \pm 1.6 \mathrm{sec}$, at $1.5 \mathrm{hr} 18 \pm 2.1 \mathrm{sec}$, at $2 \mathrm{hr} 16 \pm 1.4 \mathrm{sec}$, at 3 hr $14 \pm 1.4 \mathrm{sec}$ and at $4 \mathrm{hr} 14 \pm 0.67 \mathrm{sec}$. The mean reaction time Allium cepa high dose the mean reaction time at $0 \mathrm{hr}$ $17 \pm 1.8 \mathrm{sec}$, at $0.5 \mathrm{hr} 19 \pm 1.8 \mathrm{sec}$, at $1 \mathrm{hr} 24 \pm 0.68 \mathrm{sec}$, at $1.5 \mathrm{hr} 22 \pm 2.4 \mathrm{sec}$, at $2 \mathrm{hr} 20 \pm 1.4 \mathrm{sec}$, at $3 \mathrm{hr} 15 \pm 2.4 \mathrm{sec}$ and at $4 \mathrm{hr} 15 \pm 2.6 \mathrm{sec}$. The mean reaction time with ibuprofen at $0 \mathrm{hr} 15 \pm 1.7 \mathrm{sec}$, at $0.5 \mathrm{hr} 20 \pm 1.9 \mathrm{sec}$, at $1 \mathrm{hr}$ $23 \pm 1.2 \mathrm{sec}$, at $1.5 \mathrm{hr} 24 \pm 1.3 \mathrm{sec}$, at $2 \mathrm{hr} 25 \pm 1.2 \mathrm{sec}$, at $3 \mathrm{hr}$ $16 \pm 3.2 \mathrm{sec}$ and at $4 \mathrm{hr} 14 \pm 1.4 \mathrm{sec}$ respectively.

Table 1: Effects Allium cepa on Eddys hot plate method in rats, data presented as mean \pm SD.

\begin{tabular}{|c|c|c|c|c|c|}
\hline Hours & $\begin{array}{l}\text { Control } \\
\mathrm{N} \text { saline (NS) } \\
2.5 \mathrm{ml} / \mathrm{kg}\end{array}$ & $\begin{array}{l}\text { Allium cepa } \\
\text { (ACL) } \\
8 \mathrm{ml} / \mathrm{kg}\end{array}$ & $\begin{array}{l}\text { Allium cepa } \\
(\mathrm{ACH}) \\
16 \mathrm{ml} / \mathrm{kg}\end{array}$ & $\begin{array}{l}\text { Ibuprofen } \\
\text { (B) } \\
20 \mathrm{mg} / \mathrm{kg}\end{array}$ & Significance at $p<0.05$ \\
\hline $\mathbf{0 . 0}$ & $18 \pm 1.5$ & $16 \pm 1.9$ & $17 \pm 1.8$ & $15 \pm 1.7$ & No significance \\
\hline 0.5 & $13 \pm 1.3$ & $19 \pm 2.1$ & $19 \pm 1.8$ & $20 \pm 1.9$ & No significance \\
\hline 1.0 & $13 \pm 2.6$ & $18 \pm 1.6$ & $24 \pm 0.68$ & $23 \pm 1.2$ & NS vs. ACH, NS vs. B \\
\hline 1.5 & $14 \pm 1.6$ & $18 \pm 2.1$ & $22 \pm 2.4$ & $24 \pm 1.3$ & NS vs. B \\
\hline 2.0 & $15 \pm 2.9$ & $16 \pm 1.4$ & $20 \pm 1.4$ & $25 \pm 1.2$ & NS vs. ACH, NS vs. B \\
\hline 3.0 & $13 \pm 1.3$ & $14 \pm 1.4$ & $15 \pm 2.4$ & $16 \pm 3.2$ & No significance \\
\hline 4.0 & $15 \pm 1.3$ & $14 \pm 0.67$ & $15 \pm 2.6$ & $14 \pm 1.4$ & No significance \\
\hline
\end{tabular}

The mean reaction time increased significantly $(\mathrm{p}<0.05)$ with high dose of Allium cepa at $1 \mathrm{hr}$ and $2 \mathrm{hr}$ when compared to control. The mean reaction time increased significantly $(\mathrm{p}<0.05)$ with ibuprofen at $1 \mathrm{hr}, 1.5 \mathrm{hr}$ and
$2 \mathrm{hr}$ when compared to control. Allium cepa in the dose of $16 \mathrm{ml} / \mathrm{kg}$ shows statistically significant $(\mathrm{p}<0.05)$ analgesic activity. However, we did not find a significant different activity with low dose allium cepa as compared to saline (Table 1). 


\section{Tail flick method}

The mean reaction time in control group at $0 \mathrm{hr}$ was $4.50 \pm 0.34 \mathrm{sec}$, at $0.5 \mathrm{hr} 4.83 \pm 0.31 \mathrm{sec}$, at $1 \mathrm{hr} 5.00 \pm 0.26$ $\mathrm{sec}$, at $1.5 \mathrm{hr} 4.00 \pm 0.37 \mathrm{sec}$. With Allium cepa low dose, it was at $0 \mathrm{hr} 4.50 \pm 0.34 \mathrm{sec}$, at $0.5 \mathrm{hr} 5.00 \pm 0.37 \mathrm{sec}$, at 1 hr $5.33 \pm 0.33 \mathrm{sec}$, at $1.5 \mathrm{hr} 5.67 \pm 0.42 \mathrm{sec}$. The mean reaction time with Allium cepa high dose was at $0 \mathrm{hr}$ $4.50 \pm 0.22 \mathrm{sec}$, at $0.5 \mathrm{hr} 6.00 \pm 0.26 \mathrm{sec}$, at $1 \mathrm{hr} 7.00 \pm 0.26$ $\mathrm{sec}$, at $1.5 \mathrm{hr} 8.50 \pm 0.43 \mathrm{sec}$. The mean reaction time in ibuprofen group at $0 \mathrm{hr} 4.67 \pm 0.21 \mathrm{sec}$, at $0.5 \mathrm{hr} 5.83 \pm 0.31$ sec, at $1 \mathrm{hr} 7.00 \pm 0.37 \mathrm{sec}$, at $1.5 \mathrm{hr} 9.00 \pm 0.37 \mathrm{sec}$. The mean reaction time increased significantly $(\mathrm{p}<0.05)$ with high dose of Allium cepa at $1 \mathrm{hr}$ and $1.5 \mathrm{hr}$ when compared to control. The mean reaction time increased significantly $(\mathrm{p}<0.05)$ with ibuprofen at $1 \mathrm{hr}$ and $1.5 \mathrm{hr}$ when compared to control. However, we did not find a significant different activity with low dose Allium cepa as compared to saline. Allium cepa in the dose $16 \mathrm{ml} / \mathrm{kg}$ shows statistically significantly analgesic activity (Table 2).

Table 2: Effects Allium cepa on tail flick method in rats, data presented as mean \pm SD.

\begin{tabular}{|c|c|c|c|c|c|}
\hline Hours & $\begin{array}{l}\text { Control } \\
\text { N saline (NS) } \\
2.5 \mathrm{ml} / \mathrm{kg}\end{array}$ & $\begin{array}{l}\text { Allium cepa } \\
(\text { ACL) } \\
8 \mathrm{ml} / \mathrm{kg}\end{array}$ & $\begin{array}{l}\text { Allium cepa } \\
\text { (ACH) } \\
16 \mathrm{ml} / \mathrm{kg}\end{array}$ & $\begin{array}{l}\text { Ibuprofen } \\
\text { (B) } \\
20 \mathrm{mg} / \mathrm{kg}\end{array}$ & Significance at $p<0.05$ \\
\hline 0.0 & $4.50 \pm 0.34$ & $4.50 \pm 0.34$ & $4.50 \pm 0.22$ & $4.67 \pm 0.21$ & No Significance \\
\hline 0.5 & $4.83 \pm 0.31$ & $5.00 \pm 0.37$ & $6.00 \pm 0.26$ & $5.83 \pm 0.31$ & No Significance \\
\hline 1.0 & $5.00 \pm 0.26$ & $5.33 \pm 0.33$ & $7.00 \pm 0.26$ & $7.00 \pm 0.37$ & NS vs. ACH, NS vs. B \\
\hline 1.5 & $4.00 \pm 0.37$ & $5.67 \pm 0.42$ & $8.50 \pm 0.43$ & $9.00 \pm 0.37$ & NS vs. ACH, NS vs. B \\
\hline
\end{tabular}

Table 3: Effects Allium cepa on carrageenan induced rat paw edema method, data presented as mean \pm SD.

\begin{tabular}{|llllll|} 
Hours & $\begin{array}{l}\text { Control } \\
\text { N saline (NS) } \\
\mathbf{2 . 5} \mathbf{~ m l} / \mathbf{k g}\end{array}$ & $\begin{array}{l}\text { Allium cepa } \\
\text { (ACL) }\end{array}$ & $\begin{array}{l}\text { Allium cepa } \\
\text { (ACH) }\end{array}$ & $\begin{array}{l}\text { Ibuprofen } \\
\text { (B) }\end{array}$ & Significance at $\mathbf{p}<\mathbf{0 . 0 5}$ \\
$\mathbf{1 6 . 0}$ & $0.21 \pm 0.02$ & $0.21 \pm 0.02$ & $0.19 \pm 0.00$ & $0.19 \pm 0.00$ & No Significance \\
\hline $\mathbf{0 . 5}$ & $0.27 \pm 0.02$ & $0.25 \pm 0.02$ & $0.22 \pm 0.02$ & $0.20 \pm 0.00$ & No Significance \\
\hline $\mathbf{1 . 0}$ & $0.42 \pm 0.03$ & $0.42 \pm 0.03$ & $0.35 \pm 0.02$ & $0.32 \pm 0.03$ & NS vs. B, ACH vs. NS \\
\hline $\mathbf{1 . 5}$ & $0.42 \pm 0.02$ & $0.45 \pm 0.02$ & $0.40 \pm 0.03$ & $0.42 \pm 0.02$ & No Significance \\
\hline $\mathbf{2 . 0}$ & $0.49 \pm 0.03$ & $0.50 \pm 0.02$ & $0.48 \pm 0.03$ & $0.43 \pm 0.03$ & NS vs. B \\
\hline $\mathbf{3 . 0}$ & $0.55 \pm 0.02$ & $0.55 \pm 0.02$ & $0.54 \pm 0.03$ & $0.53 \pm 0.02$ & No Significance \\
\hline $\mathbf{4 . 0}$ & $0.56 \pm 0.02$ & $0.57 \pm 0.02$ & $0.55 \pm 0.03$ & $0.51 \pm 0.02$ & No Significance \\
\hline
\end{tabular}

\section{Carrageenan rat paw method}

The paw volume in the control group at $0 \mathrm{hr} 0.21 \pm 0.02$ $\mathrm{ml}$, at $0.5 \mathrm{hr} 0.27 \pm 0.02 \mathrm{ml}$, at $1 \mathrm{hr} 0.42 \pm 0.03 \mathrm{ml}$, at $1.5 \mathrm{hr}$ $0.42 \pm 0.02 \mathrm{ml}$, at $2 \mathrm{hr} 0.49 \pm 0.03 \mathrm{ml}$, at $3 \mathrm{hr} 0.55 \pm 0.02 \mathrm{ml}$ at $4 \mathrm{hr} 0.56 \pm 0.02 \mathrm{ml}$. The paw volume in the Allium cepa low dose at $0 \mathrm{hr} 0.21 \pm 0.02 \mathrm{ml}$, at $0.5 \mathrm{hr} 0.25 \pm 0.02 \mathrm{ml}$, at $1 \mathrm{hr} 0.42 \pm 0.03 \mathrm{ml}$, at $1.5 \mathrm{hr} 0.45+0.02 \mathrm{ml}$, at $2 \mathrm{hr}$ $0.50+0.02 \mathrm{ml}$, at $3 \mathrm{hr} 0.55+0.02 \mathrm{ml}$, at $4 \mathrm{hr} 0.57+0.02 \mathrm{ml}$. The paw volume in the Allium cepa high dose at $0 \mathrm{hr}$ $0.19 \pm 0.00 \mathrm{ml}$, at $0.5 \mathrm{hr} 0.22 \pm 0.02 \mathrm{ml}$, at $1 \mathrm{hr} 0.35 \pm 0.02$ $\mathrm{ml}$, at $1.5 \mathrm{hr} 0.40 \pm 0.02 \mathrm{ml}$, at $2 \mathrm{hr} 0.48 \pm 0.03 \mathrm{ml}$, at $\mathrm{hr}$ $0.54 \pm 0.03 \mathrm{ml}$, at $4 \mathrm{hr} 0.55 \pm 0.03 \mathrm{ml}$. The paw volume in the Ibuprofen group time at $0 \mathrm{hr}$ was $0.19 \pm 0.00 \mathrm{ml}$, at 0.5 hr $0.20 \pm 0.00 \mathrm{ml}$, at $1 \mathrm{hr} 0.32 \pm 0.03 \mathrm{ml}$, at $1.5 \mathrm{hr} 0.42 \pm 0.02$ $\mathrm{ml}$, at $2 \mathrm{hr} 0.43 \pm 0.03 \mathrm{ml}$, at $3 \mathrm{hr} 0.53 \pm 0.02 \mathrm{ml}$, at $4 \mathrm{hr}$ $0.51 \pm 0.02 \mathrm{ml}$. Allium cepa in high dose exhibited antiinflammatory activity by significant $(\mathrm{p}<0.05)$ suppression of paw edema when compare to control at $1 \mathrm{hr}$ after carrageenan injection to rat paw. Ibuprofen exhibited anti-inflammatory activity by significant $\quad(\mathrm{p}<0.05)$ suppression of paw edema when compare to control at 1 $\mathrm{hr}$ and $2 \mathrm{hr}$ after carrageenan injection to rat paw (Table $3)$.

\section{DISCUSSION}

In current study, three different methods have been applied in order to identify the possible analgesic as well as anti-inflammatory effects of fresh onion juice in rats. The analgesic effect of fresh onion juice was studied via two different processes, results obtained from hot plate test and tail flick effect was seen with high dose of Alium cepa $16 \mathrm{ml} / \mathrm{kg}$ weight, a significant difference only with control group $(\mathrm{p}<0.05)$ and not with standard drug ( $>0.05$ ). However, low dose of Alium cepa $8 \mathrm{ml} / \mathrm{kg}$ weight failed to show significant response as compared to control. Results obtained from carrageenan rat paw edema test indicate a strong anti-inflammatory effect was seen with high dose of Alium cepa $16 \mathrm{ml} / \mathrm{kg}$ weight, a significant difference only with control group $(\mathrm{p}<0.05)$ and not with standard drug $(\mathrm{p}>0.05)$. Lanzotti et al used 
hot plate and formalin tests to study in analgesic of fresh onion juice $(7.5 \mathrm{ml} / \mathrm{kg})$ in mice during acute and chronic pain stages modeling. A significant analgesic property for fresh onion juice in both pain phases was recorded; the effect was similar to that of morphine $(5 \mathrm{mg} / \mathrm{kg})$. Fresh onion juice also decreased the hind paw thickness significantly. ${ }^{13}$ In current study, low dose of Alium cepa 8 $\mathrm{ml} / \mathrm{kg}$ weight failed to show significant response as compared to control. The possible explanations include species variation of onion, pharmacokinetic of onion or ethnic variation in rats. According to some studies, fresh onion juice is capable of inhibiting arachidonic acid metabolism and so it can prevent formation of leukotrienes and thromboxanes, via inhibiting COX and LOX (lipoxygenase) pathways responsible for its antiapoptotic effect. ${ }^{14-16}$ On the other hand, it was proven that flavonoids express anti-inflammatory properties by which they inhibit the proliferation and activity of lymphocytes. ${ }^{17}$

According to high content of flavonoids such as quercetin in onion juice and extract, it can be claimed that this potent anti-inflammatory effect might be because of quercetin. ${ }^{13}$ Moreover, one paper suggested that onion can cause analgesia as well as local anesthesia via mitochondria; which encouraged us towards assessment of the analgesic capability for fresh onion juice. ${ }^{18}$ Ibuprofen is the NSAID with the most inhibition towards the chronic stage via COX inhibition. ${ }^{19}$ According to the literature, reduction in pain, inflammation and the signal transduction pathway(s) responsible for both phenomena mentioned above, results in a decline in plasticity at dorsal root of spinal cord via deprivation in $\mathrm{P}$ substance and/or stimulant amino acids such as glycine and glutamate from nerve endings. ${ }^{20}$ In addition, there is a substance called ajoene found both in garlic and onion which has been proposed to inhibit the pain receptors at dorsal root of spinal cord, thus resulting in an inhibition of pain signal transduction. ${ }^{21}$ So further investigation on the mechanism of action of the plant extract, as well as the active substance responsible for its biological actions is necessary.

\section{CONCLUSION}

Allium cepa has significant analgesic and antiinflammatory activity in hot plate, tail flick and carrageenan induced paw edema model.

Funding: No funding sources Conflict of interest: None declared

Ethical approval: The study was approved by the Institutional Ethics Committee

\section{REFERENCES}

1. Devi B, Sharma N, Kumar D, Jeet K. Morusalbalinn: a phytopharmacological review. Int J Pharm Pharm Sci. 2013;5(2):14-8.
2. Michael W, Rabow SZ, Pantilat SS, Ramana KN. Palliative care \& pain management In: Maxine AP, Stephen JM. Current medical diagnosis \& treatment. 58 ${ }^{\text {th }}$ ed. USA: McGraw Hill; 2019:82.

3. Frederickson NF, David M. Introduction to immunity and inflammation. In: Bruntom LL, Lazo JS, Parker KL. Goodmans and Gilman's the pharmacological basis of therapeutics. 13th ed. USA: McGraw Hill; 2018:630.

4. Brickell C. The royal horticultural society encyclopedia of gardening. USA: Dorling Kindersley; 1992:345.

5. Griffiths G, Trueman L, Crowther T, Thomas B, Smith B. Onions - A global benefit to health. Phytother Res. 2002;16(7): 603-15.

6. Sivam, GP. Protection against Helicobacter pylori and other bacterial infections by garlic. J Nutr. 2001;131(3):1106-8.

7. Akash MS, Rehman K, Chen S. Spice plant Allium cepa: dietary supplement for treatment of type 2 diabetes mellitus. Nutrition. 2014;30(10):1128-37.

8. Marrelli M, Amodeo V, Statti G, Conforti F. Biological Properties and Bioactive Components of Allium cepa L.: Focus on Potential Benefits in the Treatment of Obesity and Related Comorbidities. Molecules. 2018;24(1):119.

9. Boyle SP, Dobson VL, Duthie SJ, Kyle JA, Collins AR. Absorption and DNA protective effects of flavonoid glycosides from an onion meal. Eur J Nutr. 2000;39(5):213-23.

10. Kalus U, Pindur G, Jung F, Mayer B, Radtke H, Bachmann K, Mrowietz C, Koscielny J, Kiesewetter $\mathrm{H}$. Influence of the onion as an essential ingredient of the Mediterranean diet on arterial blood pressure and blood fluidity. Arzneimittelforschung. 2000;50(9): 795-801.

11. Marefati N, Ghorani V, Shakeri F. A review of antiinflammatory, antioxidant, and immunomodulatory effects of Allium cepa and its main constituents. Pharm Biol. 2021;59(1):287-302.

12. Gupta R, Tyagi P, Prakash J. Analgesic and antiinflammatory drugs. In: Gupta SK eds. Drug screening methods. 2nd ed. New Delhi: Jaypee Brothers Medical; 2009:461-97.

13. Lanzottiv A. The analysis of onion and garlic. J Chrmotogr. 2006;11(12):213-20.

14. Lindegaard C, Gleerup KB, Thomsen MH, Martinussen T, Jacobsen N, Andersen PH. Antiinflammatory effects of intra-articular administration of morphine in horses with experimentally induced synovitis. AJVR. 2010;71(1):69-75.

15. Dorsch W, Wagner H, Bayer T, Fessler B, Hein G, Ring J, et al. Anti-asthmatic effects of onions: Alkenyl sulfinothioic acid alkenyl-esters inhibit histamine release, leukotriene and thromboxane biosynthesis in vitro and counteract PAF and allergen-induced bronchial obstruction in vivo. Biochem Pharm.1988;37(23):4479-86.

16. Alpsoy S, Aktas C, Uygur R, Topcu B, Kanter M, Erboga $\mathrm{M}$, et al. Antioxidant and anti-apoptotic 
effects of onion (Allium cepa) extract on doxorubicin-induced cardiotoxicity in rats. J Appl Toxicol. 2011;13(5):258-66.

17. Recio MC, Giner RM, Manes S, Gubells L, Gueh J, Julien HR, HoststtmannK. Anti-inflammatory activity of flavonol glycosides from Erythrospermummonticolum depending on single or repeated local TPA administration. Planta Med. 1995;61(6):502-4.

18. Nouette-Gaulain K, Jose C, Capdevila X, Rossignol R. From analgesia to myopathy: When local anesthetics impair the mitochondrion. Int $\mathrm{J}$ Biochem Cell Biol. 2011;43(1):14-9.

19. Randolph BC, Peters MA. Analgesic effectiveness of ketorolac compared to meperidine in the rat formalin test. J Anesth Prog. 1997;44(1):11-6.
20. Willis WD. Role of neurotransmitters in sensitization of pain responses. Ann NY Acad Sci. 2001;933:14256.

21. Yassaka RT, Hidetoshi H, Tsuchiyoshi FT. Enhanced activation of the transient receptor potential channel TRPA1 by ajoene, an allicin derivative. Neurosci Res. 2010;66(1):99-105.

Cite this article as: Meegada PP, Pathapati RM, Rayam S, Nallabothula RK. Evaluation of analgesic and anti-inflammatory properties of the Allium cepa extract in rats. Int J Basic Clin Pharmacol 2021;10:789-94. 